\title{
Globalizing Solidarity: Praxis and the International Labor Movement
}

\author{
by \\ Bradley Nash, Jr. \\ Department of Sociology \\ Virginia Polytechnic Institute and State University \\ bnash@,vt.edu
}

Cite: Nash, Bradley Jr. (1998). "Globalizing Solidarity: Praxis and the International Labor Movement." Journal of World-Systems Research http://jwsr.ucr.edu/ 4: 1 - 3.

(C) 1997 Bradley Nash, Jr.

\section{[Page 1]}

Journal of World-Systems Research

Efforts to foster labor solidarity on a global level are nothing new. With a lineage that stretches at least as far back as the First International in the 1860 s, such projects have been part and parcel to world-system dynamics for well over a century. For a variety of reasons, however, virtually all of these previous attempts at organizing and mobilizing the workers of the world have repeatedly failed to achieve widespread and long-lasting success in their struggle against capitalist globalization. Yet despite this bleak history, those sympathetic to the plight of working peoples have not retreated into a fatalistic pessimism regarding the viability of a truly potent global labor movement. Indeed, enthusiasm about the prospects for a more globalized labor solidarity presently abounds, as evidenced for example by recent issues of Monthly Review (July -August 1997) and Work and Occupations (August 1997) devoted specifically to the topic.

Importantly, this current wave of optimism regarding the possibilities for international working class solidarity is arguably more warranted than earlier movements in this direction. Specifically, previous attempts at labor transnationalism were typically guided more by collective fervor (e.g. Second International) or party dogma (e.g. Third International) and less by theoretically-guided assessments of historical realities and potentialities. As the twentieth century draws to a close, however, the material conditions of the world-system have clearly ripened in this respect. Take note, for example, of the increasing formal integration of national and regional economies (e.g. EEC, NAFTA), the fall of the Soviet Union and the marked relaxation of East-West tensions, and most significantly, the continual globalization of capitalist production. Overall, then, the present juncture is clearly quite amenable to, and perhaps even demands, the establishment of a global labor movement.

Of course, such an outcome is neither historically inevitable or even highly probable. Furthermore, the success or failure of such an international labor movement is another issue entirely. Globalizing labor solidarity simultaneously requires both practice informed by theory and theorizing informed by practice, and it is in this respect that this special 
issue of JWSR hopes to make some contribution. All of the pieces presented here are directly concerned with issues pertaining to labor and global praxis. While some of the contributions are more empirically-oriented case studies of current efforts at cross-border organizing and others are more conceptual or programmatic in nature, each aims to highlight some of the practical and theoretical issues that must be addressed in efforts to foster labor solidarity throughout the world-system.

The contributions collected here are similar in another respect as well. Presented primarily to facilitate discussion and debate, they have not been subjected to an extensive peer review process as have most other articles appearing in the JWSR. Indeed, much of the material to follow was written for other venues or purposes. For example, the first contribution, the forum on the "Problems and Prospects for a Global Labor Movement", initially appeared in the Summer 1997 issue of PEWS News, the official newletter of the American Sociological Association's Section on the Political Economy of the WorldSystem. In addition, the pieces by Bonacich and Armbruster represent later versions of papers presented this past summer in Toronto at the annual meeting of the American Sociological Association. Only the article by Stevis was written specifically for this special issue. In any event, it was felt by the guest editor and editor alike that the JWSR, as an electronic journal with greater flexibility than traditional print publications, would serve as an ideal outlet for these timely assessments on global praxis and the labor movement.

[Page 2]

Journal of World-Systems Research 